\title{
URGENSI PENDIDIKAN POLITIK DALAM MENCIPTAKAN PEMILU DAMAI DI SULAWESI SELATAN (PENDEKATAN SOSIOLOGI POLITIK)
}

\author{
Askar Nur \\ UIN Alauddin Makassar \\ askarr.nur@gmail.com
}

\begin{abstract}
ABSTRAK
Penelitian ini menjelaskan tentang urgensi dari pendidikan politik dalam upaya menciptakan situasi dan kondisi damai dalam prosesi pemilihan umum (Pemilu) di Sulawesi Selatan. Penelitian ini merupakan penelitian deskriptif dengan menggunakan metode kualitatif dan pendekatan sosiologi politik Maurice Duverger. Penelitian ini dilaksanakan dengan tujuan mengidentifikasi konflik atau permasalahan lainnya baik dalam pemilu maupun pilkada di Sulawesi Selatan. Setelah melakukan proses penelusuran, peneliti menemukan bahwa variabel yang mampu menciptakan konsepsi pemilu atau pilkada damai dan jujur adalah dengan meningkatkan mutu pembelajaran kepada masyarakat selaku pemilih dalam hal ini pendidikan politik.
\end{abstract}

Kata Kunci: Pendidikan Politik, Pemilu, Pilkada, Sulawesi Selatan

\begin{abstract}
This research explains about the urgency of politics education for creating calm and honestly situation and condition in general election process in South Sulawesi. This research is descriptive research using qualitative method and Maurice Duverger's politics sociology approach. This research is conducted for identifying conflict or other problem either general or district election in South Sulawesi. After doing research process, the researcher found that variable which is able to create calm and honestly general or district election concept is to increase learning quality to the society as elector in this case politics education.
\end{abstract}

Keywords: Politics Education, General Election, District Election, South Sulawesi 


\section{PENDAHULUAN}

Menciptakan kestabilan dan kesejahteraan bagi masyarakat merupakan salah satu dari beberapa tujuan ultim dari negara. Konsepsi bernegara tidak terlepas daripada tanggung jawab dalam memberikan jaminan kesejahteraan kepada seluruh masyarakat. Dalam rangka mencapai tujuan tersebut maka dipandang perlu dan atau dibutuhkan kehadiran sosok pemimpin yang memiliki kapasitas dan integritas dalam mencapai tujuan dari walfare state.

Prosesi pemilihan pemimpin tidak terlepas daripada prinsip demokratis sesuai amanah UUD 1945 dalam hal ini masyarakat diberikan kebebasan dalam memilih suatu perkara khususnya dalam hal memilih pemimpin yang tetap mengedepankan asas dan prinsip demokrasi. Indonesia sebagai negara hukum dan menjunjung tinggi nilai-nilai demokrasi merupakan ciri khas tersendiri sepanjang sejarah kelahirannya (Zega et al., 2019).

Dalam proses memilih pemimpin tentunya dibutuhkan sebuah perangkat atau wadah tersendiri yang mampu mendukung lahirnya sosok pemimpin berdasarkan pilihan masyarakat. Tercatat sejak tahun 1955, Indonesia telah menyelenggarakan pemilu (pemilihan umum) yang merupakan proses dalam memilih seseorang untuk menduduki posisi kepemimpinan di negeri ini (Rohim \& Wardana, 2019).

Pelaksanaan pemilu pada tahun 1955 diselenggarakan dua kali berdasarkan amanat UU No. 7 Tahun 1953 dengan keterangan sebagai berikut:

1) Pemilu pertama dilaksanakan pada tanggal 29 September 1955 untuk memilih anggota-anggota Dewan Perwakilan Rakyat (DPR). Pemilihan Umum pertama diikuti oleh 11 peserta yang terdiri dari 36 partai politik, 34 organisasi kemasyarakatan, dan 48 perorangan.

2) Pemilihan Umum kedua dilakukan pada 15 Desember 1955 untuk memilih anggota-anggota Dewan Konstituante. Pemilihan Umum kedua diikuti oleh 91 peserta yang terdiri dari 39 partai politik, 23 organisasi kemasyarakatan, dan 29 perorangan (Solihah, 2018).

Pemilu pada tahun 1955 menggunakan sistem proporsional atau sistem berimbang. Hal ini berarti bahwa kursi yang tersedia dibagikan kepada partai politik sesuai dengan imbangan perolehan suara yang didapat oleh partai politik. Pada sistem ini wilayah negara adalah daerah pemilihan (Purba, Sivadabert, 2015). Namun, karena wilayah negara yang terlalu luas maka dibagikan berdasarkan daerah pemilihan dengan membagi sejumlah kursi dengan perbandingan jumlah penduduk.

Selanjutnya, pemilu pada tahun 1971 yang dilaksanakan pada Masa Orde Baru berdasarkan UU No. 15 Tahun 1969. Pemilu kedua ini diselenggarakan pada tanggal 5 Juli 1971 (Masrizal \& Sos, 2016). Pemilu 1971 bertujuan memilih anggota Dewan Perwakilan Rakyat (DPR) dengan sistem perwakilan berimbang (proporsional) dengan stelsel daftar. Jumlah partai politik nasional yang mengikuti Pemilihan Umum 1971 adalah 10 partai politik nasional. Partai politik tersebut terdiri dari Partai Nadhalatul Ulama, Partai Muslim Indonesia, Partai Serikat Islam Indonesia, Persatuan Tarbiyah Islamiiah, Partai Nasionalis Indonesia, Partai Kristen Indonesia, Partai Katholik, Partai Ikatan Pendukung Kemerdekaan Indonesia, Partai Murba, dan Sekber Golongan Karya (Sair, 2016).

Hal yang sangat membedakan dengan Pemilu 1955 adalah para pejabat negara diharuskan bersikap netral. Namun pada praktiknya, para pejabat pemerintah berpihak kepada salah satu peserta pemilu yaitu Golkar. Pembagian kursi Pemilu 1971 juga 
berbeda dengan Pemilu 1955, yaitu semua kursi terbagi habis di setiap daerah pemilihan (Sinamora, 2019).

Ketiga, pemilu pada periode 1977-1997 menggunakan sistem yang sama dengan pemilu 1971. pemilu pada Masa Orde Baru ini diawali pada tanggal 2 Mei 1977 (Yustiningrum et al., 2015). Pada pemilu periode ini terjadi peleburan atau fusi parpol peserta pemilu, sehingga hanya diikuti oleh 3 partai politik nasional yaitu:

1) Partai Golongan Karya

2) Partai Persatuan Pembangunan (PPP) yang merupakan gabungan dari Partai NU, Parmusi, Perti, dan PSII. Baca juga artikel mengenai sejarah Partai PPP.

3) Partai Demokrasi Indonesia (PDI) yang merupakan gabungan dari PNI, Partai Katolik, Parkindo, Partai IPKI, dan Partai Murba.

Setelah pemilu 1977, pemilu berikutnya selalu diselenggarakan setiap 5 tahun sekali. Hal lain yang membedakan adalah sejak Pemilu 1977 pesertanya jauh lebih sedikit, yaitu dua partai politik dan Golkar (Efyanti et al., 2019). Pemilu pada periode ini pemenangnya selalu sama, yaitu Golkar.

Keempat, pemilu 1999 yang persiapannya tergolong singkat, tetapi pemilu tetap dilakukan sesuai jadwal yaitu 7 Juni 1999. Pemilu 1999 merupakan penanda pemilihan pertama pada Masa Reformasi dan dilakukan serentak di seluruh Indonesia. Pemilu 1999 juga menandai kebangkitan demokrasi di Indonesia (Liando, 2016). Hal ini terbukti dari banyaknya jumlah peserta yang mengikuti pemilihan, yaitu sebanyak 48 partai politik.

Cara pembagian kursi pada pemilu kali ini tetap menggunakan sistem proporsional dengan mengikuti varian Roget (Bashori, 2018). Hal ini berarti bahwa sebuah partai memperoleh kursi seimbang dengan suara yang diperolehnya di daerah pemilihan. Namun, ada yang berbeda dengan cara penetapan calon terpilih dibandingkan dengan pemilu periode sebelumnya. Pada Pemilu kali ini, calon terpilih ditetapkan berdasarkan suara terbesar atau terbanyak dari daerah tempat seseorang dicalonkan (Tata et al., 2019). Hal ini berbeda dengan sejak Pemilu 1977, pada saat itu nomor urut pertama dalam daftar calon partai secara otomatis terpilih apabila partai itu mendapat kursi.

Kelima, pemilu tahun 2004 dimana masyarakat secara langsung dapat memilih DPR, DPD, DPRD, Presiden, dan Wakil Presiden. Pemilu 2004 dilaksanakan secara serentak pada 5 April 2004 untuk memilih 550 anggota DPR, 128 anggota DPD serta DPRD untuk periode 2004-2009. Pemilihan Presiden dan Wakil Presiden RI dilaksanakan pada 5 Juli 2004 (Putaran I) dan 20 September 2004 (Putaran II). Pemilihan Presiden dan Wakil Presiden pada Pemilihan Umum 2004 dimenangkan oleh Susilo Bambang Yudhoyono (Presiden) dan Jusuf Kalla (Wakil Presiden).

Pemilu 2004 menunjukkan kemajuan demokrasi di Indonesia. Masyarakat dapat memilih secara langsung dan bukan lagi melalui anggota MPR seperti pemilu sebelumnya. Selain itu, pemilu 2004 juga diikuti oleh banyak partai politik peserta pemilu. Partai peserta pemilu 2004 yakni Partai Buruh Sosial Demokrat; Partai Merdeka; Partai Perhimpunan Indonesia Baru; Partai Nasional Banteng Kemerdekaan; Partai Persatuan Nahdlatul Ummah Indonesia; Partai Patriot Pancasila; Partai Sarikat Indonesia; Partai Persatuan Daerah, Partai Pelopo; Partai Nasional Indonesia Marhaenisme; Partai Keadilan dan Persatuan Indonesia, dan Partai Penegak Demokrasi Indonesia. Partai Karya Peduli Bangsa; Partai Pelopor; Partai Persatuan Demokrasi Kebangsaan; Partai Damai Sejahtera; Partai Bulan Bintang; Partai Persatuan Pembangunan; Partai Demokrat; Partai Amanat Nasional; Partai Kebangkitan Bangsa; 
Partai Keadilan Sejahtera; Partai Bintang Reformasi; Partai Demokrasi Indonesia Perjuangan; dan Partai Golongan Karya (Suryana, 2020).

Keenam, pemilu 2009 adalah pemilihan umum kedua setelah pemilu 2004 yang diikuti dengan pemilihan langsung Presiden dan Wakil Presiden Republik Indonesia. Pasangan calon terpilih pada pemilihan presiden dan wakil presiden adalah pasangan yang memperoleh suara lebih dari $50 \%$ dari jumlah suara dengan sedikitinya $20 \%$ suara di setiap provinsi yang tersebar lebih dari 50\% jumlah provinsi di Indonesia. Peserta pemilu 2009 untuk pemilihan anggota DPR, DPD, dan DPRD diikuti oleh 44 partai politik, yaitu 3 partai nasional dan 6 partai lokal Aceh. Pemilihan Presiden dan Wakil Presiden pada Pemilihan Umum 2009 dimenangkan oleh Susilo Bambang Yudhoyono (Presiden) dan Boediono (Wakil Presiden).

Ketujuh, pemilu 2014 yang diselenggarakan dua kali. Pemilu pertama dilaksanakan pada tanggal 9 April 2014 dengan tujuan pemilihan para anggota legislatif. Pemilu legislatif ini bertujuan memilih 560 anggota DPR, 132 anggota DPD, dan anggota DPRD Provinsi maupun DPRD Kabupaten/ Kota Se-Indonesia untuk periode 2014-2019. Pemilu kedua dilakukan pada tanggal 9 Juli 2014 dengan tujuan pemilihan Presiden dan Wakil Presiden (Arianto \& Ali Haji, n.d.). Pemilihan Presiden diikuti oleh dua pasang calon Presiden dan Wakil Presiden yaitu Prabowo Subianto yang berpasangan dengan Hatta Rajasa dan Joko Widodo yang berpasangan dengan Jusuf Kalla.

Pemilu 2014 diikuti oleh 10 partai politik. Partai politik tersebut adalah Partai Amanat Nasional (PAN), Partai Demokrasi Indonesia Perjuangan (PDIP), Partai Demokrat, Partai Gerakan Indonesia Raya (Gerindra), Partai Golongan Karya (Golkar), Partai Hati Nurani Rakyat (Hanura), Partai Keadilan Sejahtera (PKS), Partai Kebangkitan Bangsa (PKB), Partai Nasional Demokrat (Nasdem), dan Partai Persatuan Pembangunan (PPP). Pemilihan Presiden dan Wakil Presiden pada Pemilihan Umum 2014 dimenangkan oleh Joko Widodo (Presiden) dan Jusuf Kalla (Wakil Presiden).

Lebih lanjut, Indonesia kembali menyelenggarakan pemilihan umum di tahun 2019. Pada Pemilu 2019 ada 16 partai politik nasional yang berpartisipasi (Masyarakat et al., 2019). Keenam belas partai politik nasional tersebut adalah Partai Amanat Nasional (PAN); Partai Demokrasi Indonesia Perjuangan (PDIP); Partai Demokrat; Partai Gerakan Indonesia Raya (Gerindra); Partai Golongan Karya (Golkar); Partai Hati Nurani Rakyat (Hanura); Partai Keadilan Sejahtera (PKS); Partai Kebangkitan Bangsa (PKB); Partai Nasional Demokrat (Nasdem); Partai Persatuan Pembangunan (PPP); Partai Persatuan Indonesia (Perindo); Partai Solidaritas Indonesia (PSI); Partai Beringin Karya (Berkarya); Partai Bulan Bintang (PBB); Partai Gerakan Perubahan Indonesia (Garuda); dan Partai Keadilan dan Persatuan Indonesia (PKPI); ditambah 4 partai politik lokal Aceh yaitu Partai Aceh, Partai Sira, Partai Daerah Aceh, dan Partai Nanggroe Aceh.

Pemilu 2019 diselenggarakan secara serentak antara Pemilu Legislatif dan Pemilu Presiden dan Wakil Presiden, yaitu digelar dalam satu hari yang sama tanggal 17 April 2019. Pasangan calon Presiden dan Wakil Presiden yang bertanding dalam Pemilihan Umum Presiden 2019 adalah pasangan Joko Widodo dan Ma'ruf Amin dengan pasangan Prabowo Subianto dan Sandiaga Salahuddin Uno dan dimenangkan oleh pasangan Joko Widodo dan Ma'ruf Amin.

Sementara itu, pemilu tahun 2020 untuk pemilihan kepala daerah akan digelar serentak pada Desember 2020 mendatang. Di Sulawesi Selatan khususnya terdapat 
beberapa kandidat yang akan bertarung di masing-masing daerah. Hal tersebut tentu akan melahirkan serangkaian persaingan dari masing-masing kandidat.

Dalam konteks pemilu, salah satu tujuan dari pemilukada adalah memilih pemimpin yang berkualitas, namun demikian tujuan dari pemilukada yang damai adil justru memiliki kendala tersendiri terlebih potensi konflik yang sering terjadi pada setiap pelaksanaan pemilukada di Indonesia secara umum dan di Sulawesi Selatan khususnya. Potensi konflik pemilukada seringkali terjadi pada masyarakat, yang membawa gesekan pada level elit sehingga tujuan dari pemilukada yang damai dan adil seringkali jauh dari tujuan hadirnya Undang-Undang tentang Pemilu.

Konflik seringkali terjadi dalam proses interaksi antar-individu, individu dengan kelompok, maupun kelompok dengan kelompok yang masing-masing disebabkan oleh perbedaan baik dalam latar belakang interaksi, kemampuan berinteraksi, maupun tujuan berinteraksi (Makmur, 2020). Tidak terkecuali konflik juga terjadi pada masyarakat Indonesia yang mempunyai latar belakang politik, etnis, dan agama yang berbeda. Dari latar belakang yang beragam ini, corak konflik di Indonesia pun juga beragam.

Dalam proses pelaksanaannya, pemilihan kepala daerah (pilkada) langsung ternyata seringkali menyebabkan sejumlah persoalan terkait proses pelaksanaannya yang dinilai cenderung menghamburkan dana rakyat termasuk dugaan money politics, serta tidak jarang hasil pilkada langsung itu direspon secara negatif sehingga berbuntut kerusuhan dan kekerasan.

Money politics, politik identitas dan serangkaian konflik lainnya yang mengisyaratkan tidak berjalannya konsepsi jujur dan adil sesuai amanat UU tentang Pemilu merupakan fenomena yang acapkali mewarnai dunia perpolitikan di Indonesia khususnya di Sulawesi Selatan. Hal demikian pun menjadi penanda minimnya pendidikan politik bagi para pemilih.

Dalam pasal 1 ayat (4) UU No. 2 Tahun 2008 tentang partai politik menyebutkan bahwa pendidikan politik merupakan proses pembelajaran dan pemahaman tentang hak, kewajiban, dan tanggung jawab setiap warga negara dalam kehidupan berbangsa dan bernegara. Pasal ini menjelaskan bahwa partai politik berhak memberikan pendidikan politik kepada setiap warga negara dan setiap warga negara juga berhak menerima pendidikan itu (Amruddin, 2020).

Misalnya pendidikan politik yang diberikan oleh partai politik kepada masyarakat, dalam hal ini memberikan pendidikan politik secara berkala kepada masyarakat. Dengan adanya pendidikan politik yang diberikan oleh partai politik, maka masyarakat mulai memahami apa itu politik dan pendidikan politik. Dengan adanya pendidikan politik yang diberikan, maka masyarakat juga akan dapat memberikan partisipasi yang tepat bagi negaranya, seperti berpartisipasi dalam memberikan suara pada pemilihan umum dan terhindar dari segala konflik yang umumnya hadir dalam kontestasi perpolitikan (Freire et al., n.d.).

Senada dengan itu, pendidikan politik yang simultan akan membawa pengaruh positif kepada para masyarakat khususnya dari segi ruang sosiologi politik. Sosiologi politik sebagai bentuk perkawinan antara ilmu sosiologi dan ilmu politik yang berfokus pada masyarakat, negara dan kekuasaan untuk melihat hubungan masyarakat dengan lembaga-lembaga politik, seperti sosialisasi politik, partisipasi politik, rekrutmen politik, komunikasi politik, konflik dan demokrasi; dan hubungan masyarakat dengan lembaga politik dan proses politik secara bersamaan, seperti budaya politik dan civil society sehingga tercipta sebuah keselarasan antara kontestasi politik dan kesejahteraan 
masyarakat sebagai fokus utama dari produk-produk politik (Pahlevi \& Amrurobbi, 2020).

Oleh karena itu, penelitian ini bertujuan untuk menggambarkan urgensi pendidikan politik di Sulawesi Selatan sebagai upaya untuk menciptakan pemilu jujur dan adil melalui serangkaian masalah atau konflik yang pernah terjadi di Sulawesi Selatan dengan merujuk kepada pendekatan sosiologi politik Maurice Duverger.

\section{METODE}

Objek penelitian ini ialah fenomena-fenomena tentang masalah atau konflik pemilu yang terjadi di Sulawesi Selatan yang mengharuskan hadirnya pendidikan politik. Penelitian ini menggunakan teknik pengumpulan data dokumentasi pemberitaan masalah atau konflik pemilu yang terjadi di Sulawesi Selatan untuk memperoleh sumber data primer dan kajian pustaka untuk data sekunder. Analisis dilakukan dengan terlebih dahulu mengelompokkan pesan berdasarkan dokumentasi masalah atau konflik yang terjadi di Sulawesi Selatan. Teknik analisis penelitian menggunakan analisis sosiologi politik Maurice Duverger. Penelitian ini menekankan penyelesaian masalah dengan merujuk kepada metode penelitian kualitatif deskriptif.

\section{HASIL DAN PEMBAHASAN}

\section{Fenomena Permasalahan Pemilu di Sulawesi Selatan}

Di Sulawesi Selatan, kasus dan polemik seputaran pemilu bukan lagi menjadi rahasia dalam pandangan publik. Hampir di setiap kontestasi perpolitikan diwarnai peristiwa baik yang sifatnya lumrah maupun yang fatal (Asti, 2014). Selain maraknya pesta demokrasi yang diwarnai adegan kecurangan seperti money politics, politik identitas dan politik dinasti juga acapkali terjadi tindakan yang menyentuh ranah-ranah fisikal seperti yang pernah terjadi pasca Pemilihan Gubernur Sulawesi Selatan tahun 2009 yang membuat kondisi provinsi itu baik bidang keamanan dan stabilitas politik memanas (Sasmita, 2011).

Beberapa polemik konflik di Sulawesi Selatan selain konflik pasca Pemilihan Gubernur Sulawesi Selatan tahun 2009, juga terdapat konflik pada sejumlah daerah. Misalnya, konflik yang terjadi di Kabupaten Pangkep tahun 2005 dimana massa pada saat itu menyegel kantor KPU (Sitepu, 2016). Hal serupa juga terjadi di Kabupaten Toraja dan Kabupaten Soppeng tahun 2008. Terjadi amuk massa yang berdampak pada penyegelan kantor KPU dan rusaknya kertas suara yang dibakar massa. Hal ini dipicu oleh adanya kecurigaan massa terhadap penyelenggara pemilu yang tidak terbuka pada msyarakat dalam penghitungan suara.

Mengurai permasalahan-permasalahan yang dihadir sebelum dan sesudah pemilu tersebut yang juga berefek kepada masyarakat awam khususnya pada kehidupan masyarakat, Maurice Duverger dalam teori sosiologi politiknya mengambarkan bahwa sosiologi politik sebagai ilmu tentang kekuasaan, pemerintahan, otoritas, komando dalam semua masyarakat, yang bukan saja masyarakat nasional, tetapi juga dalam masyarakat lokal dan internasional. Jadi dapat disimpulkan bahwa sosiologi politik adalah disiplin ilmu yang mempelajari antara masyarakat dan politik; hubungan masyarakat dengan lembaga-lembaga politik di satu sisi dan masyarakat dengan proses 
politik (sosialisasi, partisipasi, rekrutmen, komunikasi dan konflik) di sisi lain (Yusnedi Achmad, S.H., 2019).

Sosiologi politik Duverger mencakup struktur politik, faktor-faktor antagonis politik, bentuk-bentuk konflik politik. Struktur politik menjelaskan batas-batas teritorial atau wilayah-wilayah kekuasaan, sumber-sumber alami, dan alat-alat teknologi yang bisa menimbulkan konflik antar individu atau kelompok dalam masyarakat. Faktorfaktor antagonis politik adalah suatu sikap yang menentang atau bertolak belakang dengan kekuasaan politik yang menjelaskan faktor-faktor timbulnya konflik antar individu atau kelompok dalam kehidupan masyarakat (Vol \& Sosial, 2010).

Antagonis politik sendiri terdiri dari kepentingan individual di antaranya bakatbakat individual serta sebab-sebab psikologis dan kepentingan kolektif diantaranya ada perjuangan kelas, konflik rasial, konflik antar kelompok horizontal, serta konflik antara kelompok teritorial. Bentuk-bentuk konflik politik menjelaskan bentuk-bentuk atau wujud-wujud dari konflik politik yang terjadi pada individu maupun kelompokkelompok dalam masyarakat.

Permasalahan dalam setiap pemilu baik pemilihan presiden dan wakil presiden maupun pilkada akan membawa pengaruh besar terhadap budaya yang terbangun dalam masyarakat. Sosiologi politik Duverger menggambarkan dampak-dampak yang ditimbulkan oleh konflik yang terjadi dalam prosesi pemilu maupun pemilukada terhadap kehidupan politik masyarakat sehingga sebuah kegelisahan tersendiri di tubuh sosial kemasyarakatan yang mengharuskan hadirnya wadah pembelajaran terkait esensi dan tujuan daripada hadirnya pemilu dan pesta-pesta demokrasi lainnya (Amsori, 2017).

Salah satu kabupaten atau kota yang ada di Sulawesi Selatan yang akan menyelenggarakan pilkada pada tahun 2020 adalah Makassar. Beberapa pakar menyebutkan bahwa pilkada 2020 di Makassar rawan akan konflik. Hal tersebut diutarakan pula oleh Komisioner Bawaslu Sulsel dalam sebuah wawancara yang dilansir di Tribun-Timur.com, setidaknya terdapat 10 dimensi yang menjadi faktor rawannya konflik dalam kontestasi pilkada 2020 di Makassar, di antaranya pemasangan alat peraga yang tidak sesuai aturan, praktik politik uang kepada pemilih untuk memilih calon tertentu, praktik mahar politik, penggunaan fasilitas negara dalam kampanye oleh peserta pemilu, peserta pemilu melakukan kampanye di luar jadwal, politik uang pada masyarakat dalam bentuk kegiatan sosial dalam memilih calon tertentu, iklan kampanye di luar jadwal, konflik antar pendukung, konflik antara peserta dan praktik uang kepada tokoh untuk memilih calon tertentu (Sukendar, 2017).

\section{Urgensi Pendidikan Politik di Sulawesi Selatan}

Keberadaan parpol dalam suatu negara merupakan konsekuensi dari lahirnya sistem demokrasi perwakilan, hal ini karena institusi partai politik memang lahir dan berkembang guna merealisasi sistem perwakilan ini. Di dalam sistem demokrasi modern (baca demokrasi perwakilan), maka parpol harus dapat memainkan peranan penting dalam proses perwakilan tersebut. Dengan demikian maka sekali partai itu terbentuk atau muncul maka ia harus segera membangun sendi-sendi yang mampu memperkuat kelangsungan demokrasi itu sendiri dan pemerintahan konstitusional.

Gagasan tentang partai politik dapat kita temukan baik pada negara yang menganut sistem politik demokratis maupun otoriter. Dalam sistem politik demokratis 
gagasan mengenai partisipasi rakyat mempunyai dasar idiologis bahwa rakyat berhak untuk turut menentukan siapa- siapa yang akan menjadi pemimpin yang nantinya akan menentukan kebijakan umum. Sementara di negara yang menganut faham otoriter gagasan partisipasi rakyat dilandasi oleh pandangan elit politiknya bahwa rakyat perlu dibimbing dan dibina untuk mencapai stabilitas yang langgeng, dan untuk mencapai hal itu parpol merupakan alat yang baik.

Beragam definisi tentang Partai Politik yang dikemukakan oleh para pakar berdasarkan perspektifnya masing-masing (Santoso, 2013). Secara umum Partai Politik merupakan suatu organisasi yang bersifat nasional dan dibentuk oleh sekelompok warga negara Indonesia secara sukarela atas dasar kesamaan kehendak dan cita-cita untuk memperjuangkan dan membela kepentingan politik anggota, masyarakat, bangsa dan negara, serta memelihara keutuhan Negara Kesatuan Republik Indonesia berdasarkan Pancasila dan Undang-Undang Dasar Negara Republik Indonesia Tahun 1945.

Menurut ketentuan Pasal 11 UU Nomor 2 tahun 2008 fungsi partai politik adalah melakukan;

1) Pendidikan politik bagi anggota dan masyarakat luas agar menjadi warga negara Indonesia yang sadar akan hak dan kewajibannya dalam kehidupan bermasyarakat, berbangsa, dan bernegara;

2) Penciptaan iklim yang kondusif bagi persatuan dan kesatuan bangsa Indonesia untuk kesejahteraan masyarakat;

3) Penyerap, penghimpun, dan penyalur aspirasi politik masyarakat dalam merumuskan dan menetapkan kebijakan negara;

4) Partisipasi politik warga negara Indonesia; dan

5) Rekrutmen politik dalam proses pengisian jabatan politik melalui mekanisme demokrasi dengan memperhatikan kesetaraan dan keadilan gender.

Secara normatif pendidikan politik oleh partai politik, baru mulai dicantumkan dalam UU parpol sejak era reformasi melalui UU Nomor 3 Tahun 1999 jo UU Nomor 31 Tahun 2002 dan UU Nomor 2 Tahun 2008. Sementara pada masa Orde Baru melalui UU Nomor 3 Tahun 1975 jo UU Nomor 3 Tahun 1985 fungsi pendidikan politik tidak dibebankan pada parpol namun dilaksanakan oleh pemerintah. UU Nomor 2 Tahun 2008 menjadi undang-undang pertama yang secara spesifik mengamanatkan perlunya pendidikan politik dengan memperhatikan keadilan dan kesetaraan gender yang ditujukan untuk meningkatkan kesadaran akan hak dan kewajiban, meningkatkan partisipasi politik dan inisiatif warga negara, serta meningkatkan kemandirian dan kedewasaan dalam kehidupan berbangsa dan bernegara.

Pendidikan politik harus terus ditingkatkan agar terbangun karakter bangsa yang merupakan watak atau kepribadian bangsa Indonesia yang terbentuk atas dasar kesepahaman bersama terhadap nilai-nilai kebangsaan yang lahir dan tumbuh dalam kehidupan bangsa, antara lain kesadaran kebangsaan, cinta tanah air, kebersamaan, keluhuran budi pekerti, dan keikhlasan untuk berkorban bagi kepentingan bangsa (Hemafitria, 2015).

Pendidikan politik dalam undang-undang ini didefinisikan sebagai proses pembelajaran dan pemahaman tentang hak, kewajiban, dan tanggung jawab setiap warga negara dalam kehidupan berbangsa dan bernegara. Komitmen ini lebih dipertegas dalam Bab ke VIII Pasal 31 dengan menyatakan, bahwa:

1) Partai Politik melakukan pendidikan politik bagi masyarakat sesuai dengan ruang lingkup tanggung jawabnya dengan memperhatikan keadilan dan kesetaraan gender dengan tujuan antara lain: 
a) Meningkatkan kesadaran hak dan kewajiban masyarakat dalam kehidupan bermasyarakat, berbangsa, dan bernegara;

b) Meningkatkan partisipasi politik dan inisiatif masyarakat dalam kehidupan bermasyarakat, berbangsa, dan bernegara; dan

c) Meningkatkan kemandirian, kedewasaan, dan membangun karakter bangsa dalam rangka memelihara persatuan dan kesatuan bangsa.

2) Pendidikan politik sebagaimana dimaksud pada ayat (1) dilaksanakan untuk membangun etika dan budaya politik sesuai dengan Pancasila.

Di samping itu pendidikan politik juga menjadi kewajiban dari partai politik sebagaimana ketentuan dalam Pasal 13 huruf e yang menyatakan bahwa parpol berkewajiban melakukan pendidikan politik dan menyalurkan aspirasi politik anggotanya. Berbagai fungsi partai politik tersebut yang meliputi pendidikan politik, stabilitas politik, partisipasi politik, seleksi kepemimpinan dan penyalur aspirasi rakyat belum bisa dilaksanakan secara proporsional (Muwazah \& 2011, n.d.).

Urgensi pendidikan politik itu didasarkan pada asumsi kedaulatan rakyat yang mempunyai postulat bahwa pemerintahan yang adil adalah, siapa yang memperoleh kekuasaan, dia itulah yang bertanggung jawab. Manakala rakyat mendapat kekuasaan menurut dasar kedaulatan rakyat, maka rakyat pulalah yang bertanggung jawab. Menurut Mohammad Hatta (1980), hal itu berarti, jika rakyat tak memiliki kesadaran politik, maka rasa tanggung jawabnya akan amat kurang. Menurut Hatta, pemerintah dan masyarakat sama-sama berkepentingan adanya rakyat yang mempunyai kesadaran politik. Karena itu, pendidikan politik harus datang dari kedua belah pihak (Hemafitria, 2015).

Pada satu sisi, pemerintah bisa memudahkan jalan pendidikan politik dengan mempertinggi kecerdasan umum rakyat; sedangkan dari masyarakat, pendidikan politik merupakan tanggung jawab utama bagi partai-partai politik. Bagi masyarakat yang secara politis sudah menjadi pemilih tradisional dengan indikator keanggotaannya dalam parpol, pendidikan politik tetap penting sekalipun mungkin menjadi nomor dua sesudah kampanye atau pemantapan kader. Partisipasi politik mereka tidak layak diragukan karena interes politiknya telah terbangun.

Sementara bagi massa mengambang, pendidikan politik akan menemukan urgensi dan relevansinya. Massa mengambang inilah yang harus menjadi fokus voter education, sebab di samping kelompok apolitik dan golput berada di sana, kelompok ini juga paling rentan (rawan) terhadap praktik money politics (politik uang) (Putri, 2017). Meskipun terdapat perbedaan definisi massa mengambang, ada satu hal yang jelas bahwa kelompok sasaran yang menjadi bagian massa mengambang setidaknya terdiri dari rakyat awam non-anggota parpol, para wirausahawan dan profesional, pegawai dan bekas pegawai negeri (PNS, wredhatama, KBA dan purnawirawan), pegawai/ karyawan swasta, wartawan/jurnalis, serta mahasiswa dan intelektual.

Sebagian kecil di antara mereka memang sudah mengecap pendidikan politik lewat beragam wahana sehingga mereka ada memiliki kesadaran politik.akan tetapi pengetahuan mereka tentang kondisi riel politik justru akan meningkatkan kecuekan dan sikap apolitiknya. Tujuan pendidikan politik setidaknya agar para calon pemilih yang sudah terdaftar tidak akan berubah menjdi golput di bilik suara saat pencoblosan/pencontrengan dalam Pemilu (Adi Soeprapto, Susilasti DN, 2015).

Urgensi pendidikan politik secara khusus juga sangat dibutuhkan di Sulawesi Selatan. Melalui analisis sosiologi politik Duverger terhadap permasalahan politik di 
seputaran pemilu ataupun pemilukada yang melahirkan sebuah struktur sosial dan politik dalam kehidupan masyarakat yang secara tidak langsung mampu melahirkan arena budaya baru dalam masyarakat yang tergantung pada dinamika politik yang dihadapi (Supriadi, 2018).

Massifnya sosialisasi tentang pendidikan politik dalam ruang lingkup masyarakat Sulawesi Selatan akan semakin membuat masyarakat dewasa dalam menghadapi dinamika politik dan juga mampu terhindar dari praktik-praktik politik praktis. Sebagai upaya dalam menciptakan pemilih cerdas dan jujur maka hal yang mendasar yang perlu dikumandangkan adalah pendidikan politik itu sendiri. Bagi Duverger, terdapat beberapa lembaga yang dapat difungsikan sebagai wadah pendidikan bagi masyarakat sehingga hal demikian mampu menciptakan situasi dan kondisi yang tenteram khususnya ruang sosiologi masyarakat dalam memandang konsep perpolitikan seperti lembaga kepemudaan dan lembaga kebudayaan.

Minimnya pendidikan politik menjadi pemicu mendasar dari lahirnya konflik dan masalah-masalah baik dalam kontestasi pemilu maupun pemilukada (Nadir \& Wardani, 2019). Keharusan bagi partai politik dalam memberikan pendidikan politik kepada masyarakat tentu bukanlah variabel satu-satunya yang dapat digunakan melainkan terdapat beberapa variabel lainnya seperti mahasiswa yang melakukan pembinaan di pedesaan atau dalam hal ini pelaksanaan KKN (Kuliah Kerja Nyata) yang menjadi ruang pengedukasian mahasiswa terhadap masyarakat desa. Hal tidak boleh luput dalam konsep pembinaan tersebut adalah edukasi politik bagi masyarakat setempat.

Dimulai dari pemahaman mendasar tentang hakikat dan urgensi pemilu atau pemilukada hingga bagaimana menjadi pemilih yang kritis, yang mampu memilih calon pemimpin berdasarkan gagasan ideologis sehingga praktik-praktik kecurangan dalam prosesi pemilu mampu diminimalisir secara perlahan (Yusriati \& Amrizal, 2020). Konstruksi pemilu dan pilkada yang memiliki orientasi dan prinsip demokrasi tentu merupakan perkara yang ideal akan tetapi perkara tersebut harus didukung oleh segenap pemahaman dasar terkait politik dan kaitannya terhadap kehidupan masyarakat.

\section{KESIMPULAN}

Urgensi pendidikan politik demi menciptakan pemilu damai dan jujur khususnya di Sulawesi Selatan merupakan perkara dasar dan ultim. Maurice Duverger dalam analisa sosiologi politiknya memaparkan analisisnya tentang konstruksi sosialkemasyarakatan yang damai dan tenteram dibangun berdasarkan pemahaman terkait dunia perpolitikan.

Memahami pendidikan politik di masyarakat merupakan hal yang sangat menarik untuk diketahui. Karena pendidikan politik itu merupakan suatu proses dialogik diantara pemberi dan penerima pesan. Melalui proses ini para anggota masyarakat mengenal dan mempelajari nilai-nilai, norma-norma, dan simbol-simbol politik negaranya dari berbagai pihak dalam sistem politik seperti sekolah, pemerintah, dan partai politik. Pendidikan politik mengajarkan masyarakat untuk lebih mengenal sistem politik negaranya.

Selain itu, hadirnya pendidikan politik dalam kehidupan masyarakat pada umumnya mampu mempengaruhi partisipasi masyarakat dalam prosesi pemilu maupun pilkada serta mampu meminimalisir Golput. Seperti kita ketahui bersama bahwa 
sebagian pemilih pemula masih dipengaruhi ikatan emosional dan komersial dalam menentukan pilihan politiknya. Kecenderungan irasional dari pemilih pemula ini hendaknya dapat dihindari melalui pendidikan politik yang secara intensif dilakukan pemerintah melalui KPU, partai politik dan mahasiswa. Pemerintah tidak bisa melepaskan tanggung jawab pelaksanaan pendidikan politik kepada LSM. Partai politik pun harus mampu membuktikan komitmennya kepada pemilih pemula hingga pemilih pemula tidak enggan berpartisipasi dalam kehidupan politik dan kenegaraan.

Hasil dari penelitian ini pada akhirnya memberikan gambaran tentang penyebab terjadinya konflik dan permasalahan seputaran pemilu dan pilkada. Hal tersebut dapat diantisipasi dengan melibatkan beberapa elemen dalam masyarakat baik KPU, Partai Politik, mahasiswa maupun lembaga kepemudaan serta kebudayaan dalam memberikan pendidikan politik kepada masayarakat sebagai pemilih sehingga dengan demikian kontestasi perpolitikan dapat berjalan damai dan jujur sesuai amanah UU tentang Pemilu serta meningkatkan kedewasaan masyarakat dalam hal pemilihan pemimpin ke depannya.

\section{SARAN}

Hasil penelitian ini diharapkan kedepannya dapat dikembangkan lebih lanjut mengingat pentingnya pendidikan politik sebagai upaya menciptakan pemilu dan pilkada damai dan jujur serta mampu meningkatikan kedewasaan masyarakat dalam memilih pemimpin. Pengembangan yang dimaksud misalnya dapat dilakukan dengan membahas tentang konsep pendidikan politik sebagai upaya mengantisipasi golput dalam konstestasi politik yang tidak dibahas secara komprehensif di dalam peneltian ini.

\section{REFERENSI}

Adi Soeprapto, Susilasti DN, B. A. S. (2015). Komunikasi Dalam Proses Pendidikan Politik Pemilih Pemula Dalam Pemilihan Umum 2014 di DIY. Jurnal Ilmu Komunikasi, 12(1), 39-54.

Amruddin, A. (2020). Pilkada Serentak Dan Potensi Konflik Di Sulawesi-Selatan. Jurnal Arajang, 3(1), 30-42. https://doi.org/10.31605/arajang.v3i1.584

Amsori. (2017). Penyuluhan Pendidikan Politik Bagi Pemilih Pemula Guna Meningkatkan Partisipasi Hak Pilih Pada Pemilihan Gubernur Dki Jakarta Tahun 2017. Journal of Empowerment, 1(1).

Arianto, B., \& Ali Haji, R. (n.d.). Analisis Penyebab Masyarakat Tidak Memilih Dalam Pemilu. 2011, 1(1), 51-60.

Asti, I. M. (2014). Pengaruh Tayangan Indonesia Lawyers Club "Tvone” Terhadap Peningkatan Pendidikan Politik Masyarakat Gunung Kelua Samarinda. Ejournal.Ilkom.Fisip-Unmul.Ac.Id, 2(3), 94-108. https://ejournal.ilkom.fisipunmul.ac.id/site/wp-content/uploads/2014/08/ika maya -genap- (08-21-14-04-0555).pdf

Bashori, K. (2018). Pendidikan Politik di Era Disrupsi. Sukma: Jurnal Pendidikan, 2(2), 287-310. https://doi.org/10.32533/02207.2018 
Efyanti, Y., Zufriani, Z., \& Halim, H. (2019). Pemilihan Umum (Pemilu) Langsung di Indonesia Perspektif Sosiologis dan Hukum Islam. Al-Qisthu: Jurnal Kajian IlmuIlmu Hukum, 17(2), 51-60. https://doi.org/10.32694/010770

Freire, P., Indonesia, B., Tertindas, P. K., \& Pembebasan, P. (n.d.). Pendidikan berpola dialog yang berjalur kritis-progresif digambarkan oleh Paulo Freire dalam dua bukunya yang telah diterjemahkan ke dalam Bahasa Indonesia, Pendidikan Kaum Tertindas dan Pendidikan sebagai Praktek Pembebasan, buku yang berisi pemikiran radikal dalam dunia pendidikan meskipun ia sendiri tidak pernah menganggap karyanya seperti itu.

Hemafitria. (2015). Pembelajaran pkn sebagai pendidikan politik pemilih pemula. Edukasi, 13(2), 175-189.

Liando, D. M. (2016). PEMILU DAN PARTISIPASI POLITIK MASYARAKAT ( Studi Pada Pemilihan Anggota Legislatif Dan Pemilihan Presiden Dan Calon Wakil Presiden Di Kabupaten Minahasa Tahun 2014 ). Jurnal LPPM Bidang EkoSosBudKum, 3(2), 14-28.

https://ejournal.unsrat.ac.id/index.php/lppmekososbudkum/article/viewFile/17190/ 16738

Makmur, Z. (2020). Membangun Kesadaran Apokaliptik melalui Sastra di Masa Pandemi. https://osf.io/preprints/utvyk/

Masrizal, O., \& Sos, S. I. (2016). Gelombang Transformasi Sosial Politik Dalam Kajian Foucault dan Coleman (Kajian Sosiologis Pergolakan Partai Lokal dan Nasional di Pilkada Aceh). Jurnal Sosiologi USK (Media Pemikiran \& Aplikasi), 9(1), 35-54.

Masyarakat, P., Pedurungan, K., Politik, P., \& Hukum, D. A. N. (2019). Laporan penelitian reguler. 407.

Muwazah, A. S.-J. of, \& 2011, undefined. (n.d.). Urgensi Pendidikan Politik Bagi Perempuan. E-Journal.Iainpekalongan.Ac.Id, 325-333. http://ejournal.iainpekalongan.ac.id/index.php/Muwazah/article/view/7

Nadir, N., \& Wardani, W. Y. (2019). Membangun Pendidikan Politik Dalam Fatsun Demokrasi Pancasila Dan Deliberative. The Journal of Society \& Media, 3(1), 126. https://doi.org/10.26740/jsm.v3n1.p126-141

Pahlevi, M. E. T., \& Amrurobbi, A. A. (2020). Pendidikan Politik dalam Pencegahan Politik Uang Melalui Gerakan Masyarakat Desa. Jurnal Antikorupsi INTEGRITAS, 6(1), 141-152.

Purba, Sivadabert, A. (2015). Potret Pandangan Akademisi Di Jurnal Ilmu Sosial Dan Ilmu Politik UGM ( JSP ) Mengenai Permasalahan Demokrasi Di Indonesia. Jurnal Politik Muda, 4(1), 1-12.

Putri, N. E. (2017). Dampak Literasi Politik Terhadap Partisipasi Pemilih Dalam Pemilu. Jurnal Agregasi : Aksi Reformasi Government Dalam Demokrasi, 5(1). https://doi.org/10.34010/agregasi.v5i1.219 
Rohim, M., \& Wardana, A. (2019). Analisis Politik Milenial : Persepsi Siswa SMA Terhadap Dinamika Politik Pada PEMILU 2019 di Indonesia. JIP (Jurnal Ilmu Pemerintahan) : Kajian Ilmu Pemerintahan Dan Politik Daerah, 4(1), 47-63. https://doi.org/10.24905/jip.4.1.2019.47-63

Sair, A. (2016). Kampus dan Degradasi Pengetahuan Politik Mahasiswa. Jurnal Sosiologi Pendidikan Humanis, 1(1), 9-20. https://doi.org/10.17977/um021v1i12016p009

Santoso, M. A. F. (2013). Kontribusi Etika Islam pada Pendidikan Politik: Solusi bagi Problema Civil Society Indonesia Era Reformasi. Tsaqafah, 9(2), 225. https://doi.org/10.21111/tsaqafah.v9i2.51

Sasmita, S. (2011). Peran_Informasi_Politik_Terhadap_Partisi. Administratio, 1(2), 217-224. https://s3.amazonaws.com/academia.edu.documents/38692998/abstrak.pdf?AWSA ccessKeyId=AKIAIWOWYYGZ2Y53UL3A\&Expires $=1555825447 \&$ Signature $=6$ x9rqN2jNC\%2FySDQ1\%2B3MOU\%2BqznaQ\%3D\&response-contentdisposition=inline $\% 3 \mathrm{~B}$ filename\%3DPERAN_INFORMASI_POLITIK_TERHADAP

Sinamora, J. (2019). Menyongsong Rezim Pemilu Serentak. Jurnal RechtsVinding, 3(4), $1-18$.

Sitepu, E. (2016). Peranan Partai Politik dalam Memberikan Pendidikan Politik Yang Berkarakter Terhadap Masyarakat. Jurnal Ilmiah Research Sains, 2(1), 1-8.

Solihah, R. (2018). Peluang dan tantangan pemilu serentak 2019 dalam perspektif politik. Jurnal Ilmiah Ilmu Pemerintahan, 3(1), 73. https://doi.org/10.14710/jiip.v3i1.3234

Sukendar, M. U. (2017). Pemilihan Presiden, Media Sosial Dan Pendidikan Politik Bagi Pemilih Pemula. Ikon, 1(5), 1-6.

Supriadi, H. (2018). Prodi ilmu pemerintahan fisip unikom. Agresi, 6(2), 139-148.

Suryana, Y. (2020). Pengaruh Pelaksanaan Pemilihan Umum Serentak Terhadap Budaya Politik. Supremasi Hukum: Jurnal Penelitian Hukum, 29(1), 13-28.

Tata, K., Pemilu, K., Ilmu, F., Dan, S., Politik, I., \& Andalas, U. (2019). NUSANTARA : Jurnal Ilmu Pengetahuan Sosial PENDIDIKAN POLITIK BAGI MASYARAKAT SEBAGAI. 6(2), 314-328.

Vol, S., \& Sosial, I. (2010). DALAM PENDIDIKAN POLITIK Peran Komisi Pemilihan Umum ............. Yusuf, A . R Peran Komisi Pemilihan Umum ............. Yusuf, A.R. 4(1), 13-16.

Yusnedi Achmad, S.H., M. H. (2019). Sosiologi Politik. 79. https://books.google.co.id/books?id=t3uMDwAAQBAJ\&printsec=frontcover\&dq= sosiologi+politik\&hl=id\&sa=X\&ved=2ahUKEwiI89KTk7bqAhVfILcAHcnDBQY Q6AEwAXoECAYQAg\#v=onepage $\& \mathrm{q}=$ =sosiologi politik\&f=false 
Yusriati, Y., \& Amrizal, D. (2020). Efektivitas Model Pendidikan Politik Dalam Pelaksanaan Sosialisasi Pemilu di Kabupaten Deli Serdang. Warta Dharmawangsa, 14(3), 500-507. https://doi.org/10.46576/wdw.v14i3.831

Yustiningrum, Emilia, R., Ichwanuddin, \& Wawan. (2015). Partisipasi Politik dan Perilaku Memilih pada Pemilu 2014. Jurnal Penelitian Politik. Jurnal Penelitian Politik, 12(1), 117-135.

Zega, M. A., Muda, I., Batubara, B. M., \& Suharyanto, A. (2019). Pengaruh Program Rumah Pintar Pemilu terhadap Partisipasi Politik Masyarakat pada Kantor Komisi Pemilihan Umum Kota Medan. Perspektif, 7(2), 60.

https://doi.org/10.31289/perspektif.v7i2.2531 